\title{
First record of Foulassi Screeching Frog, Arthroleptis adelphus (Perret, 1966) (Anura, Arthroleptidae, Arthroleptinae), from Nigeria, with notes on its phylogenetic position
}

\author{
Lotanna Micah Nneji ${ }^{1}$, Adeniyi Charles Adeola ${ }^{1}$, Agboola Okeyoyin $^{2}$, Abiodun Biodun Onadeko ${ }^{3}$, \\ Edem Archibong Eniang ${ }^{4}$, Akindele Oluwatosin Adeyi ${ }^{5}$, Segun Olayinka Oladipo ${ }^{6}$, Babatunde \\ Emmanuel Adedeji ${ }^{5}$, John Yinamga Usongo ${ }^{7}$, Andem Bassey Andem ${ }^{8}$, Obih Alex Ugwumba ${ }^{5}$, \\ Adiaha Alda Alex Ugwumba ${ }^{5}$, Caroline Olory ${ }^{9}$
}

1 State Key Laboratory of Genetic Resources and Evolution, Kunming Institute of Zoology, Chinese Academy of Sciences, Kunming 650223, China. 2 National Park Service Headquarters, Federal Capital Territory, Abuja, Nigeria. 3 Department of Zoology, Faculty of Science, University of Lagos, Lagos, Nigeria. 4 Department of Forestry and Wildlife, University of Uyo, Uyo, Akwa Ibom State, Nigeria. 5 Department of Zoology, Faculty of Science, University of Ibadan, Ibadan, Oyo State, Nigeria. 6 Department of Biosciences and Biotechnology, Kwara State University, Malete, Kwara State, Nigeria. 7 Department of Zoology, Modibbo Adama University of Technology, Yola, Nigeria. 8 Department of Zoology and Environmental Biology, Faculty of Biological Sciences, University of Calabar, Nigeria. 9 Cross River National Park, Akamkpa, Nigeria.

Corresponding author: Lotanna M Nneji, lotannanneji@gmail.com

\begin{abstract}
We report the first known occurrence of the Foulassi Screeching Frog, Arthroleptis adelphus (Perret, 1966), from Nigeria. A specimen of $A$. adelphus was collected during herpetological survey work conducted in Cross River National Park, south-eastern Nigeria. Morphometrics and mitochondrial 16S rRNA gene confirm identity of the specimen. Matrilineal genealogy reveals a sister relationship of $A$. adelphus from Nigeria with individuals from south-western Cameroon. Genetic analysis further shows geographic structuring and divergence among populations of A. adelphus from the Guineo-Congolian forest region. We offer updates to the IUCN geographic range of A. adelphus.
\end{abstract}

\section{Keywords}

Cross River National Park, Guineo-Congolian forest region, range extension, sub-Saharan Africa

Academic editor: Ross MacCulloch | Received 13 January 2019 | Accepted 21 February 2019 | Published 1 March 2019

Citation: Nneji LM, Adeola AC, Okeyoyin A, Onadeko AB, Eniang EA, Adeyi AO, Oladipo SO, Adedeji BE, Usongo JY, Andem AB, Ugwumba OA, Ugwumba AAA, Olory C (2019) First record of Foulassi Screeching Frog, Arthroleptis adelphus (Perret, 1966) (Anura, Arthroleptidae, Arthroleptinae), from Nigeria, with notes on its phylogenetic position. Check List 15 (2): 253-258. https://doi.org/10.15560/15.2.253

\section{Introduction}

Species of the genus Arthroleptis Smith, 1849 are found in tropical sub-Saharan Africa (Blackburn 2008, Frost 2019). Commonly referred to as screeching frogs or squeakers, they are mostly terrestrial breeders, feeding on a range of arthropods including ants and termites
(Blackburn 2008). Currently, 48 species are known to occur in sub-Saharan Africa (Frost 2019). In Nigeria, this genus is represented by 3 species: Arthroleptis palava (Blackburn, Gvoždík \& Leaché, 2010), Arthroleptis poecilonotus (Peters, 1863), and Arthroleptis variabilis (Matschie, 1893) (AmphibiaWeb 2019). There has been no record of Arthroleptis adelphus (Perret, 1966) in 


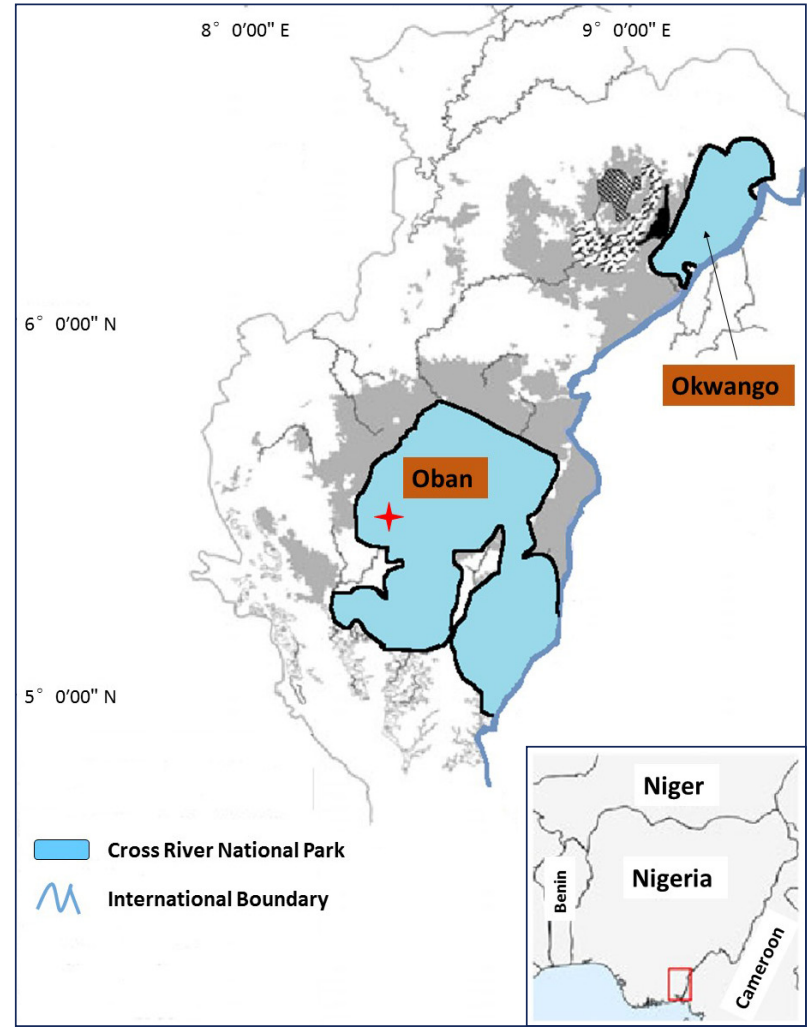

Figure 1. Map showing the sampled locality, Cross River National Park, Cross River, Nigeria. The new record of Arthroleptis adelphus was observed and collected from locality indicated by a red star.

Nigeria, although it occurs nearby in the forests of southern Cameroon, Equatorial Guinea (including Bioko), Gabon, and possibly southwestern Central African Republic and northwestern Republic of the Congo (Frost 2019). Arthroleptis adelphus is known to inhabit leaf litter within lowland forests, often avoiding marshy areas (Burger et al. 2006, IUCN 2014, Larson and Zimkus 2018). Although this species is classified by the IUCN as Least Concern, forest loss associated with agriculture, logging and human settlement could negatively impact its survival and distribution (IUCN 2014).

Herein, we report the first record of A. adelphus in Nigeria and offer updates to the IUCN geographic range for A. adelphus.

\section{Methods}

Specimen collection. Ethical approval for the field survey (NPH/GEN/121/XXV/461) was obtained from National Park Service, Abuja, Nigeria. The herpetological survey was conducted in Cross River National Park (CRNP) (Fig. 1) from 18 June to 15 December 2018. Using visual encounter survey and opportunistic observation, 5 individuals of $A$. adelphus were observed in the field by BEA and JYU during the day. However, only 1 juvenile individual was collected as the others escaped before capture. Information such as habitat type and geographic coordinates were documented. The specimen was euthanized humanely with hydrous chlorobutanol. A tissue (muscles) sample was collected and stored in
$95 \%$ ethanol. Subsequently, the voucher specimen was fixed with $4 \%$ formalin and preserved in $75 \%$ ethanol for long-term storage. The voucher and tissue samples were deposited in the museum of the Department of Zoology, University of Ibadan, Ibadan, Nigeria.

Preliminary species identification and morphometrics. Preliminary species identification followed primary literature of Zimkus and Blackburn (2008). In addition, the morphometrics of the voucher specimen were recorded. Measurements were made by BEA using a digital caliper with a precision of $0.01 \mathrm{~mm}$. Twentythree linear measurements were taken as follows: SVL (snout-vent length), HW (head width), HL (head length), TRL (trunk Length), SL (snout length), ED (eye diameter), TYD (tympanum outer diameter), ETD (eye to tympanum length), IOD (interorbital distance), FAL (fore-arm length), FL1 (first finger length), FL2 (second finger length), FL3 (third finger length), FL4 (fourth finger length), HiL (hind Limb length), TL (tibia length), SL (shank Length), FOL (foot length), TL1 (first toe length), TL2 (second toe length), TL3 (third toe length), TL4 (fourth toe length), and TL5 (fifth toe length).

Molecular laboratory protocol. Total genomic DNA of the ethanol preserved tissue was extracted following phenol-chloroform extraction procedure (Sambrook and Russell 2001). Matrilineal genealogy was inferred using mitochondrial gene fragment $16 \mathrm{~S}$ rRNA, which is commonly used as a DNA barcoding marker for African anurans (Nneji et al. 2019). An approximately 540 bp segment of 16S rRNA gene was amplified with primers designed by Bossuyt and Milinkovitch (2000). The PCR cycle profiles were as follow: 5 min initial denaturation at $94^{\circ} \mathrm{C}$, followed by 35 cycles of $1 \mathrm{~min}$ at $94{ }^{\circ} \mathrm{C}$, annealing for $45 \mathrm{~s}$ at $55^{\circ} \mathrm{C}$, extension for $1 \mathrm{~min}$ at $72{ }^{\circ} \mathrm{C}$; final extension for $10 \mathrm{~min}$ at $72{ }^{\circ} \mathrm{C}$. Purified PCR products were directly sequenced in both forward and reverse directions with an automated DNA sequencer (ABI 3730). The nucleotide sequence was viewed and confirmed manually using SeqManTMII (DNASTAR Lasergene 7). Furthermore, the amplified sequence was submitted to BLAST search in NCBI (https://blast.ncbi. nlm.nih.gov/Blast.cgi) to verify for sequence similarity.

Genetic data analysis. To further confirm the identity of the specimen and examine its phylogenetic position, our sequence was compared with others obtained from GenBank. A total of 101 16S rRNA sequences of 7 species belonging to the genus Arthroleptis from West and Central Africa were downloaded as follows: A. adelphus $(n=16)$, A. palava $(n=11)$, A. poecilinotus $(\mathrm{n}=34$ including Arthroleptis cf. poecilinotus), A. variabilis ( $n$ =15), Arthroleptis perreti (Blackburn, Gonwouo, Ernst \& Rödel, 2009) ( $n=5)$, Arthroleptis sylvaticus Laurent, $1954(n=15)$ and Arthroleptis taeniatus (Boulenger, 1906) ( $n=5)$ (Appendix Table A1). Sequences of 3 closely related species were downloaded to include as outgroup taxa: Arthroleptis formosus (Rödel, Kouame, Doumbia 

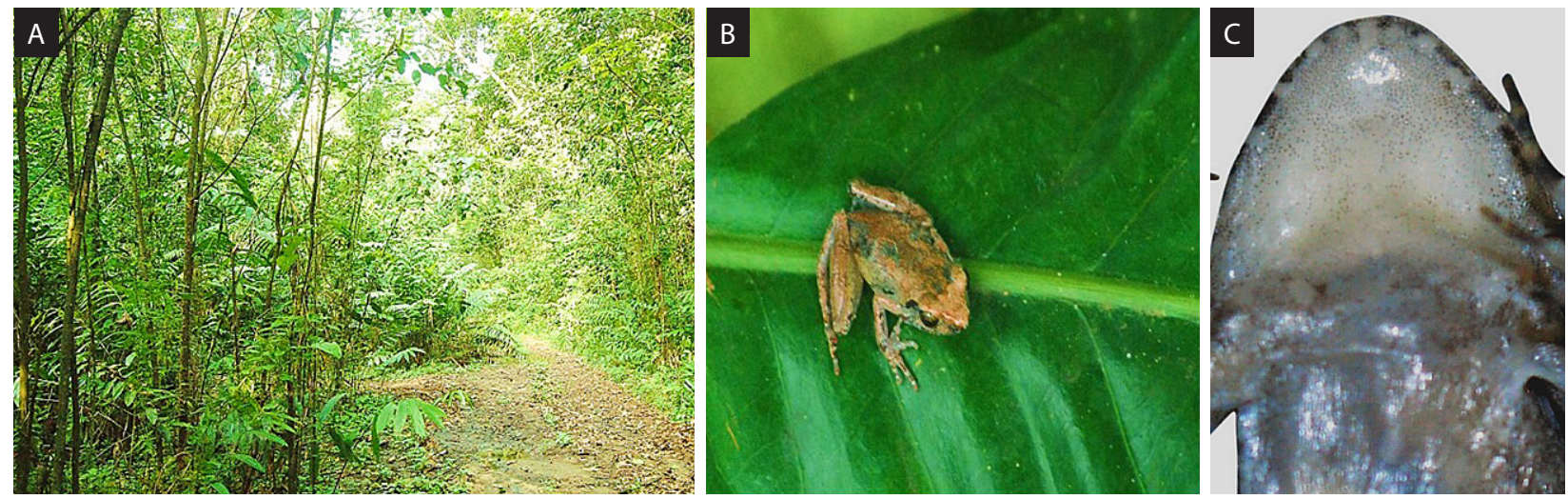

Figure 2. A. Habitat where Arthroleptis adelphus CRNPA0049 was collected. B. CRNPA0049 in life. C. Ventral view of the preserved specimen.

\& Sandberger, 2011), Arthroleptis aureoli (Schiøtz, 1964), and Arthroleptis langeri (Rödel, Doumbia, Johnson \& Hillers, 2009). Nucleotide sequences were aligned in MEGA 6.0 using ClustalW (Tamura et al. 2013) with default parameters. Hypervariable regions that could not be reliably aligned were manually excluded from the analysis, resulting in the exclusion of approximately $100 \mathrm{bp}$. The best-fit model of the nucleotide substitution was selected as GTR $+\mathrm{I}+\mathrm{G}$ using the Akaike Information Criterion as implemented in jModeltest 3.7 (Posada and Crandall 1998). The maximum likelihood (ML) was performed with RAXML v. 7.0.3 (Stamatakis 2006) using the GTR + G model with 100 random addition replicates and per partition branch lengths (Townsend et al. 2011). Reliability of the ML tree was assessed by bootstrap analysis (Felsenstein 1985) including 1000 replications. The matrilineal genealogy was visualized using FigTree v. 1.4.2 (Rambaut 2012). Nodes were considered strongly supported if they received ML bootstrap proportions $>70 \%$.

\section{Results}

\section{Arthroleptis adelphus (Perret, 1966)}

Figure 2A-C

New record. Nigeria, Cross River State, Calabar, Cross River National Park, Oban East Range, Erokut Camp $\left(05^{\circ} 21^{\prime} 89^{\prime \prime} \mathrm{N}, 008^{\circ} 26^{\prime} 46^{\prime \prime} \mathrm{E}\right), \mathrm{BEA}$ and JYU, 3 August 2018 (1 specimen, juvenile).

Our herpetological survey of CRNP discovered that Arthroleptis adelphus occurs within the lowland forest of Erokut Camp of Oban East Range, CRNP (Fig. 2A). Individuals of Arthroleptis adelphus were commonly encountered within the leaf litter of lowland forest and on vegetation $0.5-1.0 \mathrm{~m}$ above the ground. The specimen of Arthroleptis adelphus from CRNP represents the first record from Nigeria, extending this species' geographic distribution west by approximately $149.9 \mathrm{~km}$ from its nearest location in south-western Cameroon. The voucher specimen was deposited in the museum of the Department of Zoology, University of Ibadan, Nigeria, under reference number CRNPA0049. The 16S
rRNA sequence was submitted to GenBank under accession number MK377154.

Identification. The voucher specimen was morphologically identified as a member of the genus Arthroleptis by the presence of moderate pedal webbing, and the absence of tarsal tubercle, outer metatarsal tubercle, heel tubercle (located at the proximal end of the tarsus) and circummarginal groove at manual and/ or pedal digit tips. The individual was identified as juvenile because of its small body size and lack of secondary sexual characteristics. The morphological measurements of the voucher are as follows: $\mathrm{SVL}=19.10 \mathrm{~mm}, \mathrm{HW}=6.20 \mathrm{~mm}, \mathrm{HL}=7.00$ $\mathrm{mm}, \mathrm{TRL}=8.80 \mathrm{~mm}$, SL: $1.40 \mathrm{~mm}$, ED: $2.0 \mathrm{~mm}$, TYD $=1.20 \mathrm{~mm}, \mathrm{ETD}=0.8 \mathrm{~mm}, \mathrm{IOD}=1.40 \mathrm{~mm}, \mathrm{FAL}=8.70$ $\mathrm{mm}, \mathrm{FL} 1=2.40 \mathrm{~mm}, \mathrm{FL} 2=2.70 \mathrm{~mm}, \mathrm{FL} 3=3.90 \mathrm{~mm}$, FL4 $=2.10 \mathrm{~mm}, \mathrm{HiL}=10.90 \mathrm{~mm}, \mathrm{TL}=6.90 \mathrm{~mm}, \mathrm{SHL}=$ $9.00 \mathrm{~mm}, \mathrm{FOL}=15.2 \mathrm{~mm}, \mathrm{TL} 1=2.90 \mathrm{~mm}, \mathrm{TL} 2=3.40$ $\mathrm{mm}, \mathrm{TL} 3=4.20 \mathrm{~mm}, \mathrm{TL} 4=6.70 \mathrm{~mm}$, and TL5 $=3.60$ $\mathrm{mm}$. The individual could not be assigned to a species using morphology alone; thus, molecular data was used to determine the species identity.

The BLAST search for 16S rRNA sequence of our specimen showed $99 \%$ DNA sequence similarity with A. adelphus FJ151093 and FJ151092 from Cameroon. Sequence data showed that A. adelphus CRNPA0049 from Nigeria clustered genetically in a clade consisting of other A. adelphus from Central Africa (Figure 3). ML analysis revealed that CRNPA0049 formed sister group relationship with specimens FJ151093 and FJ151092 from Ejagham Forest Reserve, Southwest Cameroon (ML bootstrap proportion $=97 \%$, Fig. 3).

Distribution, natural history and conservation. $A r-$ throleptis adelphus is now known from lowland forests in southeastern Nigeria. Its documented range now extends from lowland forests of south-eastern Nigeria to southern Cameroon, Equatorial Guinea (including Bioko), and Gabon. The most common syntopic anurans in CRNP were Sclerophrys gracilipes (Boulenger, 1899) and Sclerophrys maculata (Hallowell, 1854). Considering the relatively large geographic distribution of $A$. adelphus across Central Africa, we do not consider $A$. 
(B)

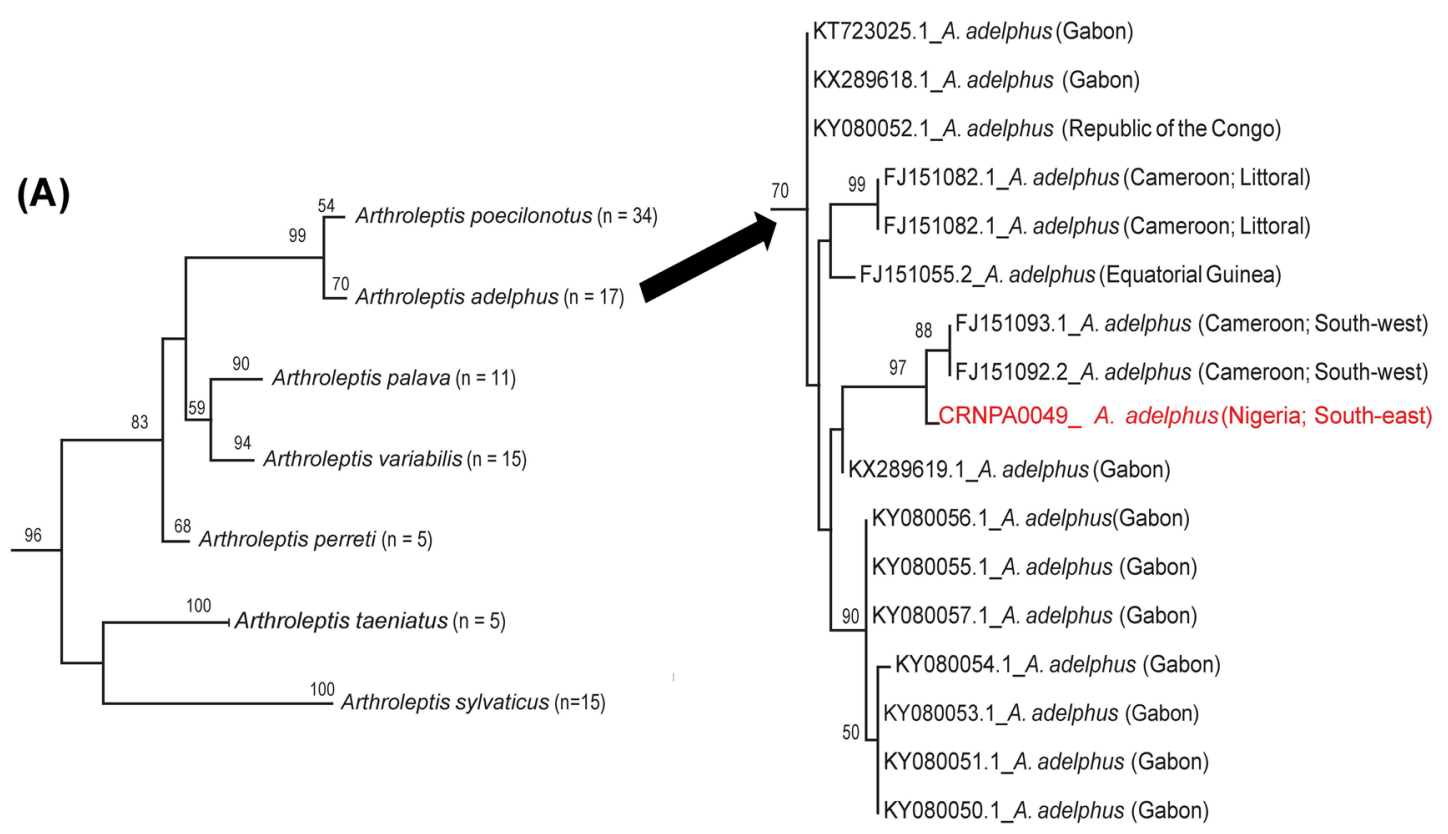

Figure 3. Matrilineal genealogy. A. Collapsed ML phylogram of some Central and West African species of the genus Arthroleptis inferred based on mtDNA $16 \mathrm{~S}$ rRNA. B. Expanded ML Phylogram showing the matrilineal relationships within the Arthroleptis adelphus species group. Numbers at each node represent the ML bootstrap values; nodes with bootstrap values above $50 \%$ are shown. The new record of A. adelphus from Nigeria is in red.

adelphus to be threatened. However, increased deforestation and agricultural practices in the region pose threats to this species. Additional field studies appear necessary to document population density and status.

\section{Discussion}

Our study documents the occurrence of $A$. adelphus from the lowland forest of south-eastern Nigeria. Previously, its distribution was thought to span across southern Cameroon, Equatorial Guinea (including Bioko), Gabon, and possibly in southwestern Central African Republic and northwestern Republic of the Congo (Burger et al. 2006, Larson and Zimkus 2018, Frost 2019). The proximity of CRNP to the border of southwestern Cameroon and habitat of the lower Guineo-Congolian forest region support the possibility of $A$. adelphus occurrence in south-eastern Nigeria. Our findings corroborate the previous study of Nneji et al. (2018) that highlighted similarities of Nigerian and Cameroonian herpetofauna due to shared environmental conditions. Our observation, therefore, strengthens the importance of extensive survey of CRNP and other regions in south-eastern Nigeria to reveal patterns of biogeographic relatedness of amphibians in the lower Guineo-Congolian forest region.

Consistent with the report of the IUCN (2014), our recent survey revealed that $A$. adelphus is closely associated with lowland forest habitats threatened by deforestation, slash and burn agricultural practices, habitat conversion, and logging. Amphibians are highly sensitive to comparatively minor forest degradation (Ernst and Rödel 2005, Ernst et al. 2006), and the destruction of habitat poses devastating effects on the population status and survival of $A$. adelphus across Central and West Africa. This calls for a concerted approach for the conservation of this species.

The phylogeny generated as part of this study was not only informative with respect to confirmation of the identity of our specimen from CRNP, but also had implications for the possibility of cryptic diversity within A. adelphus, as proposed by Deichmann et al. (2017). Divergence among populations of $A$. adelphus is evident, and CRNPA0049 is more closely related to specimens from south-western Cameroon than it is to specimens from elsewhere (Fig. 3). The type locality for A. adelphus is "Foulassi", near Sangmelima, South Cameroon (Frost 2019), and CRNPA0049 was collected near the type locality. This, therefore, provides additional confirmation regarding the validity of our specimen as $A$. adelphus. Thus, we offer recommendations for the IUCN update of the geographic range of this species.

\section{Acknowledgements}

This study was funded by National Geographic Society Grant (EC-357C-18). We are grateful to the rangers at Cross River National Park for assistance in sampling. We thank the management of National Park Service in Abuja, Nigeria for providing permission and technical assistance for the field survey. We also acknowledge the 3 anonymous reviewers and academic editor for helpful suggestions that improved this manuscript. 


\section{Authors' Contributions}

LMN designed the study; BEA and JYU collected and preserved the specimen; BEA measured the specimen; LMN performed the genetic and morphological identification; ACA, AOO, AOA, ABO, EAE, SOO, OAU, $\mathrm{ABA}, \mathrm{AAU}$ and $\mathrm{CO}$ provided technical assistance for the study and field collections; LMN, BEA, SOO and ACA wrote the initial draft of the manuscript, reviewed and finalized the manuscript; all authors read and approved the final manuscript.

\section{References}

AmphibiaWeb (2019) https://amphibiaweb.org. Accessed on: 2019-1-3. Blackburn D (2008) Biogeography and evolution of body size and life history of African frogs: Phylogeny of squeakers (Arthroleptis) and long-fingered frogs (Cardioglossa) estimated from mitochondrial data. Molecular Phylogenetics and Evolution 49 (3) 806-826. https://doi.org/10.1016/j.ympev.2008.08.015

Blackburn DC, Gvoždík V, Leaché AD (2010) A new squeaker frog (Arthroleptidae: Arthroleptis) from the mountains of Cameroon and Nigeria. Herpetologica 66 (3):335-348.

Bossuyt F, Milinkovitch MC (2000) Convergent adaptive radiations in Madagascan and Asian ranid frogs reveal covariation between larval and adult traits. Proceedings of National Academy of Sciences of the USA 97: 6585 - 6590. https://doi.org/10.1073/ pnas.97.12.6585

Burger M, Pauwells OSG, Branch WR, Tobi E, Yoga J-A, Mikolo E-N (2006) An assessment of the amphibian fauna of the complex of protected areas, Gabon. In: Alonso A, Lee ME, Campbell P, Pauwells OSG, Dallmeier F (Eds). Gamba, Gabon: Biodiversity of an equatorial African rainforest. Bulletin of the Biological Society of Washington 2: 297-307.

Deichmann JL, Mulcahy DG, Vanthomme H, Tobi E, Wynn AH, Zikmus BM, McDiarmid RW. (2017) How many species and under what names? Using DNA barcoding and GenBank data for West Central African amphibian conservation. PLoS ONE 12 (11) e0187283. https://doi.org/10.1371/journal.pone.0187283

Ernst R, Linsenmair KE, Rödel MO (2006) Diversity erosion beyond the species level: Dramatic loss of functional diversity after selective logging in two tropical amphibian communities. Biological Conservation 33: 43-55. https://doi.org/10.1016/j.biocon. 2006.05.028

Ernst R, Rödel MO (2005) Anthropogenically induced changes of predictability in tropical anuran assemblages. Ecology 86 (3): 3-8. https://doi.org/10.1890/04-0800

Ernst R, Agyei AC, Rödel MO (2008) A new giant species of Arthroleptis (Amphibia: Anura: Arthroleptidae) from the Krokosua Hills Forest. Zootaxa 1697: 58-68.

Felsenstein J (1985) Confidence-limits on phylogenies - an approach using the bootstrap. Evolution 39: 783-791. https://doi.org/ 10.1111/j.1558-5646.1985.tb00420.x

Frost DR, Grant T, Faivovich J, Bain R, Haas A, Haddad CFB, de Sa RO, Channing A, Wilkinson M, Donnellan SC, Raxworthy C, Campbell JA, Blotto BL, Moler P, Drewes RC, Nussbaum RA, Lynch JD, Green DM, Wheeler WC (2006) The amphibian tree of life. Bulletin of the American Museum of Natural History 297: 1-291. https://doi.org/10.1206/0003-0090(2006)297[0001:tatol]2 $0 . \mathrm{CO} ; 2$

Frost DR (2019) Amphibian Species of the World: an Online Reference. Version 6.0. http://research.amnh.org/herpetology/amphibia/index. html. American Museum of Natural History, New York. Accessed on: 2019-1-3

IUCN (2014) Arthroleptis adelphus. The IUCN Red List of Threatened Species 2014: e.T59660A3079603. https://doi.org/10.2305/IUCN.
UK.2014-3.RLTS.T59660A3079603.en. Accessed on: 2019-1-3.

Larson JG (Unpublished) Geographic distribution: Arthroleptis adelphus (Foulassi Screeching frog). Direct submission NCBI GenBank.

Larson JG, Zimkus BM (2018) Preliminary assessment of the frog assemblages from sites adjacent to three national Parks in Gabon. Herpetological Conservation and Biology 13 (1): 240-256.

Nneji LM, Adeola AC, Okeyoyin AO, Oladipo OC, Saidu Y, Usongo JY, Ugwumba AAA (2019) Assessing the effectiveness of molecular data for species identification and diversity studies of Nigerian herpetofauna. Mitochondrial DNA Part B 4: 589-593. https://doi.org/10.1080/23802359.2018.1561219

Nneji LM, Adeola AC, Yan F, Okeyoyin AO, Oladipo OC, Olagunju TE, Omotoso O, Oladipo SE, Iyiola OA, Auta T, Usman AD, Abdullahi H, Peng MS, Jin JQ, Murphy RW, Ugwumba AAA, Che J (2018) Cryptic lineages of Nigerian Agama (Squamata: Agamidae) within the West African radiation. Russian Journal of Herpetology 25 (2): 97-112.

Portik DM, Blackburn DC (2016) The evolution of reproductive diversity in Afrobatrachia: A phylogenetic comparative analysis of an extensive radiation of African frogs. Evolution 70 (9): 2017-2032. https://doi.org/10.1111/evo.12997

Portik DM, Jongsma GF, Kouete MT, Scheinberg LA, Freiermuth B, Nkonmeneck WPT, Blackburn DC (2016) A survey of amphibians and reptiles in the foothills of Mount Kupe, Cameroon. Amphibian and Reptile Conservation 10 (2): 37-67.

Posada D, Crandall KA (1998) Modeltest: testing the model of DNA substitution. Bioinformatics 14: 817-818. https://oi.org/10.1093/ bioinformatics/14.9.817

Rambaut A (2012) FigTree. http://tree.bio.ed.ac.uk/software/figtree. Accessed on: 2019-1-3.

Rockney HJ, Ofori-Boateng C, Porcino N, Leaché AD (2015) A comparison of DNA barcoding markers in West African frogs. African Journal of Herpetology 64: 135-147. https://doi.org/10.10 80/21564574.2015.1114530

Rödel MO, Kouame NG, Doumbia J, Sandberger L. (2011) A new beautiful squeaker frog (Arthroleptidae: Arthroleptis) from West Africa. Zootaxa 3011: 16-26.

Roelants K, Gower DJ, Wilkinson M, Loader SP, Biju SD, Guillaume K, Moriau L, Bossuyt F. (2007) Global patterns of diversification in the history of modern amphibians. Proceedings of the National Academy of Sciences of the United States of America 104 (3): 887-892. https://doi.org/10.1073/pnas.0608378104

Roelants K, Jiang J, Bossuyt F (2004) Endemic ranid (Amphibia: Anura) genera in southern mountain ranges of the Indian subcontinent represent ancient frog lineages: evidence from molecular data. Molecular Phylogenetics and Evolution 31 (2): 730-740. https://doi.org/10.1016/j.ympev.2003.09.011

Stamatakis A (2006) RAxML-VI-HPC: maximum likelihood based phylogenetic analyses with thousands of taxa and mixed models. Bioinformatics 22: 2688-2690. https://doi.org/10.1093/bioinformatics/btl446

Tamura K, Stecher G, Peterson D, Filipski A, Kumar, S (2013) MEGA6: Molecular Evolutionary Genetics Analysis Version 6.0. Molecular Biology and Evolution 30 (12): 2725-2729. https://doi. org $/ 10.1093 / \mathrm{molbev} / \mathrm{mst} 197$

Townsend TM, Mulcahy DG, Noonan BP, Sites JW, Kuczynski CA, Wiens JJ, Reeder TW (2011) Phylogeny of iguanian lizards inferred from 29 nuclear loci, and a comparison of concatenated and species-tree approaches for an ancient, rapid radiation. Molecular Phylogenetics and Evolution 61: 363-380. https://doi. org/10.1016/j.ympev.2011.07.008

Vences M, Kosuch J, Lotters S, Widmer A, Jungfer KH, Kohler J, Veith M (2000) Phylogeny and classification of poison frogs (Amphibia: dendrobatidae), based on mitochondrial 16S and 12S ribosomal RNA gene sequences. Molecular Phylogenetics and Evolution 15(1):34-40. https://doi.org/10.1006/mpev.1999.0738 Zhang P, Liang D, Mao RL, Hillis DM, Wake DB, Cannatella DC 
(2013) Efficient Sequencing of Anuran mtDNAs and a Mitogenomic Exploration of the Phylogeny and Evolution of Frogs. Molecular Biology and Evolution 30 (8): 1899-1915. https:/doi. org $/ 10.1093 / \mathrm{molbev} / \mathrm{mst} 091$
Zimkus BM, Blackburn DC (2008) Distinguishing features of the SubSaharan frog genera Arthroleptis and Phrynobatrachus: a short guide for field and museum researchers. Breviora 513: 1-12. https:// doi.org/10.3099/0006-9698(2008)513[1:DFOTSF]2.0.CO;2

\section{Appendix}

Table A1. Information of Central and West African species of the genus Arthroleptis used in the matrilineal genealogy.

\begin{tabular}{|c|c|c|c|c|c|c|c|}
\hline & Species & $\begin{array}{l}\text { GenBank } \\
\text { Accession } \\
\text { Numbers }\end{array}$ & Reference & & Species & $\begin{array}{l}\text { GenBank } \\
\text { Accession } \\
\text { Numbers }\end{array}$ & Reference \\
\hline \multicolumn{4}{|c|}{ Ingroup } & 53 & A. variabilis 8 & DQ283081 & Frost et al. (2006) \\
\hline 1 & Arthroleptis palava 1 & HM238195 & Blackburn et al. (2010) & 54 & A. variabilis 9 & FJ151058 & Blackburn (2008) \\
\hline 2 & A. palava 2 & HM238194 & Blackburn et al. (2010) & 55 & A. variabilis 10 & FJ151147 & Blackburn (2008) \\
\hline 3 & A. palava 3 & HM238193 & Blackburn et al. (2010) & 56 & A. variabilis 11 & FJ151091 & Blackburn (2008) \\
\hline 4 & A. palava 4 & HM238189 & Blackburn et al. (2010) & 57 & A. variabilis 12 & FJ151086 & Blackburn (2008) \\
\hline 5 & A. palava 5 & HM238188 & Blackburn et al. (2010) & 58 & A. variabilis 13 & AF124107 & Vences et al. (2006) \\
\hline 6 & A. palava 6 & HM238187 & Blackburn et al. (2010) & 59 & A. variabilis 14 & FJ151083 & Blackburn (2008) \\
\hline 7 & A. palava 7 & HM238186 & Blackburn et al. (2010) & 60 & A. variabilis 15 & KX289620 & Larson \& Zikmus (2018) \\
\hline 8 & A. palava 8 & FJ151150 & Blackburn (2008) & 61 & Arthroleptis adelphus 1 & KX289619 & Larson \& Zikmus (2018) \\
\hline 9 & A. palava 9 & FJ151143 & Blackburn (2008) & 62 & A. adelphus 2 & FJ151093 & Blackburn (2008) \\
\hline 10 & A. palava 10 & FJ151142 & Blackburn (2008) & 63 & A. adelphus 3 & KY080057 & Deichmann et al. (2017) \\
\hline 11 & A. palava 11 & FJ151132 & Blackburn (2008) & 64 & A. adelphus 4 & KY080056 & Deichmann et al. (2017) \\
\hline \multirow[t]{2}{*}{12} & \multirow{2}{*}{$\begin{array}{l}\text { Arthroleptis cf. } \\
\text { poecilonotus } 1\end{array}$} & \multirow[t]{2}{*}{ KY080067 } & \multirow[t]{2}{*}{ Deichmann et al. (2017) } & 65 & A. adelphus 5 & FJ151082 & Blackburn (2008) \\
\hline & & & & 66 & A. adelphus 6 & FJ151081 & Blackburn (2008) \\
\hline 13 & A. cf. poecilonotus 2 & KY080066 & Deichmann et al. (2017) & 67 & A. adelphus 7 & KY080055 & Deichmann et al. (2017) \\
\hline 14 & A. cf. poecilonotus 3 & KY080065 & Deichmann et al. (2017) & 68 & A. adelphus 8 & KY080054 & Deichmann et al. (2017) \\
\hline 15 & A. cf. poecilonotus 4 & KY080064 & Deichmann et al. (2017) & 69 & A. adelphus 9 & KY080053 & Deichmann et al. (2017) \\
\hline 16 & A. cf. poecilonotus 5 & KY080063 & Deichmann et al. (2017) & 70 & A. adelphus 10 & KY080052 & Deichmann et al. (2017) \\
\hline 17 & A. cf. poecilonotus 6 & KY080062 & Deichmann et al. (2017) & 71 & A. adelphus 11 & KY080051 & Deichmann et al. (2017) \\
\hline 18 & A. cf. poecilonotus 7 & KY080061 & Deichmann et al. (2017) & 72 & A. adelphus 12 & KY080050 & Deichmann et al. (2017) \\
\hline 19 & A. cf. poecilonotus 8 & KY080060 & Deichmann et al. (2017) & 73 & A. adelphus 13 & KT723025 & Larson (unpublished) \\
\hline 20 & A. cf. poecilonotus 9 & KY080059 & Deichmann et al. (2017) & 74 & A. adelphus 14 & FJ151092 & Blackburn (2008) \\
\hline 21 & A. cf. poecilonotus 10 & KY080058 & Deichmann et al. (2017) & 75 & A. adelphus 15 & FJ151055 & Blackburn (2008) \\
\hline 22 & Arthroleptis poecilonotus 1 & KX671725 & Portik et al. (2016) & 76 & A. adelphus 16 & KX289618 & Larson \& Zikmus (2018) \\
\hline 23 & A. poecilonotus 2 & KX671724 & Portik et al. (2016) & 77 & A. adelphus 17 & MK377154 & This study \\
\hline 24 & A. poecilonotus 3 & KX671723 & Portik et al. (2016) & 78 & Arthroleptis perreti 1 & FJ151139 & Blackburn (2008) \\
\hline 25 & A. poecilonotus 4 & KX492599 & Portik \& Blackburn (2016) & 79 & A. perreti 2 & FJ151138 & Blackburn (2008) \\
\hline 26 & A. poecilonotus 5 & $J X 564853$ & Zhang et al. (2013) & 80 & A. perreti 3 & FJ151095 & Blackburn (2008) \\
\hline 27 & A. poecilonotus 6 & FJ151114 & Blackburn (2008) & 81 & A. perreti 4 & FJ151094 & Blackburn (2008) \\
\hline 28 & A. poecilonotus 7 & FJ151113 & Blackburn (2008) & 82 & A. perreti 5 & KY080068 & Deichmann et al. (2017) \\
\hline 29 & A. poecilonotus 8 & FJ151112 & Blackburn (2008) & 83 & Arthroleptis sylvaticus 1 & KY080084 & Deichmann et al. (2017) \\
\hline 30 & A. poecilonotus 9 & FJ151111 & Blackburn (2008) & 84 & A. sylvaticus 2 & KY080083 & Deichmann et al. (2017) \\
\hline 31 & A. poecilonotus 10 & FJ151110 & Blackburn (2008) & 85 & A. sylvaticus 3 & KY080082 & Deichmann et al. (2017) \\
\hline 32 & A. poecilonotus 11 & FJ151109 & Blackburn (2008) & 86 & A. sylvaticus 4 & KY080081 & Deichmann et al. (2017) \\
\hline 33 & A. poecilonotus 12 & FJ151108 & Blackburn (2008) & 87 & A. sylvaticus 5 & KY080080 & Deichmann et al. (2017) \\
\hline 34 & A. poecilonotus 13 & FJ151090 & Blackburn (2008) & 88 & A. sylvaticus 6 & KY080079 & Deichmann et al. (2017) \\
\hline 35 & A. poecilonotus 14 & FJ151089 & Blackburn (2008) & 89 & A. sylvaticus 7 & KY080078 & Deichmann et al. (2017) \\
\hline 36 & A. poecilonotus 15 & FJ151085 & Blackburn (2008) & 90 & A. sylvaticus 8 & KY080077 & Deichmann et al. (2017) \\
\hline 37 & A. poecilonotus 16 & FJ151084 & Blackburn (2008) & 91 & A. sylvaticus 9 & KY080076 & Deichmann et al. (2017) \\
\hline 38 & A. poecilonotus 17 & HM238191 & Blackburn et al. (2010) & 92 & A. sylvaticus 10 & KY080075 & Deichmann et al. (2017) \\
\hline 39 & A. poecilonotus 18 & HM238190 & Blackburn et al. (2010) & 93 & A. sylvaticus 11 & KX492600 & Portik \& Blackburn (2016) \\
\hline 40 & A. poecilonotus 19 & HM238192 & Blackburn et al. (2010) & 94 & A. sylvaticus 12 & DQ283078 & Frost et al. (2006) \\
\hline 41 & A. poecilonotus 20 & KU166812 & Rockney et al. 2015 & 95 & A. sylvaticus 13 & FJ151087 & Blackburn (2008) \\
\hline 42 & A. poecilonotus 21 & KU166811 & Rockney et al. 2015 & 96 & A. sylvaticus 14 & FJ151148 & Blackburn (2008) \\
\hline 43 & A. poecilonotus 22 & KU166808 & Rockney et al. 2015 & 97 & A. sylvaticus 15 & FJ151106 & Blackburn (2008) \\
\hline 44 & A. poecilonotus 23 & KU166807 & Rockney et al. 2015 & 98 & Arthroleptis taeniatus 1 & KY080089 & Deichmann et al. (2017) \\
\hline 45 & A. poecilonotus 24 & KU166806 & Rockney et al. 2015 & 99 & A. taeniatus 2 & KY080088 & Deichmann et al. (2017) \\
\hline 46 & Arthroleptis variabilis 1 & AY948739 & Roelants et al. 2007 & 100 & A. taeniatus 3 & KY080087 & Deichmann et al. (2017) \\
\hline 47 & A. variabilis 2 & EU350213 & Ernst et al. (2008) & 101 & A. taeniatus 4 & KY080086 & Deichmann et al. (2017) \\
\hline 48 & A. variabilis 3 & EU350212 & Ernst et al. (2008) & 102 & A. taeniatus 5 & KY080085 & Deichmann et al. (2017) \\
\hline 49 & A. variabilis 4 & FJ151070 & Blackburn (2008) & Outc & group & & \\
\hline 50 & A. variabilis 5 & FJ151069 & Blackburn (2008) & 1 & Arthroleptis formosus & JN408726 & Rödel et al. (2011) \\
\hline 51 & A. variabilis 6 & AY322301 & Roelants et al. (2004) & 2 & Arthroleptis aureoli & JN408731 & Rödel et al. (2011) \\
\hline 52 & A. variabilis 7 & KX289621 & Larson \& Zikmus (2018) & 3 & Arthroleptis langeri & JN408724 & Rödel et al. (2011) \\
\hline
\end{tabular}

